\title{
The Effect of Position Mix, Service Quality, and Positioning on Customer Loyalty to Customer Satisfaction at XBCA Bank
}

\author{
Mochammad Jasin ${ }^{1 *}$, Harlan Bachtiar Subur ${ }^{2}$, Masroni ${ }^{3}$, Bambang Sugiyono Agus Purwono ${ }^{\text {* }}$ \\ ${ }^{1}$ Universitas Islam Negeri Syarif Hidayatullah, Jakarta, Indonesia \\ ${ }^{2}$ University of Pancasila, Jakarta,Indonesia \\ ${ }^{3,4}$ Politeknik Negeri Malang,Malang, Indonesia \\ moch.jasin@uinjkt.ac.id; bambang.sugiyono@polinema.ac.id
}

\begin{abstract}
The purpose of this research is to analysis the effect of the promotion mix, service quality, and positioning on customer loyalty to customer satisfaction at Bank XBCA Area,Main Branch Office (KCU) and Sub Branch Office (KCP) Pangeran Jayakarta. The sample in this study numbered 315 respondents from several criteria such as, age, gender, education level, and professional. The research method is quantitative approachusing Structural Equation Modeling. The research results show that the promotion mix had a significant effect on customer satisfaction with a value of 3.90>1.96. Service quality has a significant effect on customer satisfaction with a value of 2.48>1.96. Positioning affects customer satisfaction with a significant value of 7.97> 1.96. promotion mix variable, service quality, and positioning simultaneously have a significant effect on customer loyalty through customer satisfaction.
\end{abstract}

Keywords

Promotion Mix, Service Quality, Positioning, Customer Loyalty, Customer Satisfaction

Article Received: 10 August 2020, Revised: 25 October 2020, Accepted: 18 November 2020

\section{Introduction}

The tight competition in the banking sector has made entrepreneurs look for the right strategy in marketing their products. Companies are required to create a motivation and innovation that can create a very strong desire that in the end when a customer must fulfill their needs, they will actualize what is on their mind in accordance with the motivation and innovation created by the Company.

Banks are one of the institutions whose main activity is financial management such as current accounts, savings and time deposits. Bank is also known as a place to borrow money, transfer money or receive all kinds of payment and deposit. According to the Republic of Indonesia Law [1] stated that what is meant by a bank is: "a business entity collect funds from society in the form of savings and distribute it to the community in the form of credit and or other forms in order to improve the standard of living of the people at large."

Nowdays high competition between banks has spurred them to compete, in order to attract customers by providing various banking services. The main bastion so that customers do not run to competitors is that banks must establish Customer
Loyalty. Therefore, the main activity of the company at the moment is creating Customer Loyalty which is not enough with Customer Satisfaction, in addition, the elements of a good promotion mix are also needed in an effort to make customers get satisfaction and ultimately lead to Customer loyalty to Bank XBCA.

Many complex problems that occur in the banking service business have caused customer dissatisfaction. This means that it cannot be denied that service quality to customers is very important in creating customer loyalty. All company employees play a very big role in these conditions. XBCA employees, especially those receiving services such as frontliners and other employees who deal directly with customers, are XBCA representatives in assessing Customer Satisfaction and describing the company's image for customers. The ability of employees to foster confidence in customers which will affect the level of profits achieved by the company. Therefore, XBCA has implemented a Kaizen/Continues Improvement program in which all employees are more focused in their work, especially in the process of employees being fast, precise, neat and making all employees feel happy to do so in order to improve Service Quality. 
Another important aspect is also found in positioning, which is a solution for customers who want new technology to increase Customer Loyalty. Along with the development of banking technology, it starts when customers make transactions manually, namely dealing with tellers, to the development of technology that makes it easy for customers to make transactions where anytime and anywhere, one of which is through a payment machine service called an ATM (Automatic Teller Machine)

XBCA innovated e-channel (electonic channel) banking facility, in order to make it easier for customers to make transactions. Besides using XBCA ATMs, they can also use Internet Banking and Mobile Banking, these facilities are technology-based services that are still superior to other banks. This service has often received awards from a number of institutions and media, at the 2013 Indonesia Property \& Bank Award, XBCA Bank received an award as a Pioneer in Modern IT-Based Banking Services. With ATMs, customers can make financial transactions easily to provide a special value for customer, namely the value of satisfaction with the services provided by the bank. So this provides an opportunity for banks to continue to improve their services by advancing ATM technology, but Service Quality is not only seen in the presence of ATMs in paying for financial transactions, but has also started with the level of technological progress achieved by the bank, the condition of the building and the machine room. ATMs that provide a sense of comfort and security, as well as with increased facilities such as useful features to support the ease of transactions.

ATM machines are not significant reliability for a bank because this facility has become the majority in various banks. One of the mainstays of XBCA is an extensive ATM Bersama network, an ATM card facility that can be used at various merchants with Debit XBCA or XBCA Cash.

On the XBCA website, it was stated that as of June 2013, it was noted that the number of XBCA ATMs reached 12,429 units spread across Indonesia. As a large bank, XBCA is strengthened by excellent human resources and technology.

$\mathrm{XBCA}$ is committed to continuing to innovate and strive to make improvements in terms of product and service quality for the convenience and safety of customers. A wide selection of banking solutions that are specifically designed to answer all the financial needs of customers, both individuals and businesses.

The latest innovation provided by XBCA by encouraging innovative digital banking services so that customers can enjoy transactions quickly, easily, safely, and comfortably, Bank XBCA is trying to make new breakthroughs to be at the forefront of providing digital-based banking solution products. hi-tech, user-friendly, and integrated. This aims to increase customer satisfaction and loyalty. In facing competition in the banking business, Bank XBCA's strategy is to do positioning. Positioning is carried out in terms of the scope of the design and offering of the company's image so that customers or marketing targets know and consider the company's position in the eyes of competitors.

Several years ago, XBCA provided the best solution called ATM deposit withdrawal. With this ATM Deposit and Pull, customers may withdraws and deposits, also purchase and pay bills without leaving a machine. Very practical and convenient, because this ATM is not only for individual customers but also for business people. What's more interesting is that in this ATM there are two types of denominations of Rp. 50,000 (about \$ 3) and Rp. 100,000 (about \$ 6), one of which can be selected or mixed. In Asia, the Recycle ATM or Cash Recycling Machine was first introduced by Japan in 1985, followed by Korea in 1995. Since then the growth of ATM recycle is very significant because other Asian countries such as China, Taiwan, Thailand and Malaysia have also have used it.

This research was conducted at XBCAX (Ten) Office Area Pangeran Jayakarta Main Branch Office, West Jakarta which oversees 10 SubBranch Offices consisting of: Glodok Plaza SubBranch Office, Lindeteves trade center SubBranch Office, Lokasari Sub-Branch Office, Jembatan Merah Sub-Branch Office, Pinangsia Sub-Branch Office, Glodok HWI Sub-Branch Office (Hayam Wuruk Indah), Pangeran Jayakarta Sub-Branch Office, Mangga Besar Sub-Branch Office, Mangga Besar Raya Sub-Branch Office and Mandala Sub-Branch Office.

Based on the above phenomena, the title was chosen: "The Effect between Position Mix, Service Quality, and Positioning on Customer Loyalty to Customer Satisfaction at XBCA Bank." 


\section{LITERATURE STUDY}

\section{Definition}

\section{A Promotion Mix}

A promotional mix is an allocation of resources among five primary elements [2]:
a. Advertising.
b. Public relations or publicity.
c. Sales promotion.
d. Direct marketing.
e. Personal selling.

\section{Positioning}

Tanya Podus [5] stated that: "Positioning a product or a brand means developing a specific image of your company that would convey the company's values along with the advantages of its offer so that your customers would be able to easily remember it whenever they have a specific purpose in mind. In the modern market of goods and services, consumers can often feel confused if you don't "filter" what you're offering to them." The types of positioning are Category based, Consumer based, Competitor based, Benefit, Price, Attribute, and Prestige.

Positioning refers to the place that a brand occupies in the minds of the customers and how it is distinguished from the products of the competitors and different from the concept of brand awareness. In order to position products or brands, companies may emphasize the distinguishing features of their brand (what it is, what it does and how, etc.) or they may try to create a suitable image (inexpensive or premium, utilitarian or luxurious, entry-level or high-end, etc.) through the marketing mix [3-5].

\section{Service Quality}

Ali Nasith [6-10] stated that: "Service quality is a multi-dimensional research instrument or variables, designed to capture consumerexpectations and perceptions of a service quality along with the five dimensions (reliability, assurance, tangibles, empathy, andresponsiveness \}that are believed to representservice quality. Service quality is built on the expectancy-disconfirmation paradigm, which in simple terms meansthat service quality is understood as the extent to which consumers' preconsumption expectations of quality areconfirmed or disconfirmed by their actual perceptions of the service experience."

\section{Customer Satisfaction}

Philip Kotler stated that: "Customer satisfaction is a function of the difference between perceivedperformance and expectation",[9], [11]. Biljana Angelova and Jusuf Zekiri [10] stated that: "Customer satisfaction (ACSI) has three antecedents: perceived quality,perceived value, and customer expectations."

\section{Customer Loyalty}

Nebert Matelong and Bennard Nassioma [13] stated that: "Customer Loyaltyrefers to positive word of mouth, referrals, favourable attitudeand repeat purchases by customers of shoe shineenterprises.Customer loyalty is a key mediating variable in explaining customer retention, is concerned with the likelihood of a customer returning,making business referrals, providing strong word-of mouth, as well as providingreferences and publicity. Customer loyalty is considered an important source of longterm business success, and building a relationship with a customer is a good way toretain loyal customers in the long term", [12].

The components of the customer loyalty are Repeat Purchase, Positive Word of Mouth, Switching Intentions, and Referrals.

Nebert Matelong and Bennard Nassioma [13] stated that: "There is an effect between service quality towards Customer Loyalty."Biljana Angelova, and Jusuf Zekiri [10] stated that: "There is an effect between Perceived Quality and Customer Expectation on Customer Satisfaction to Perceived Value (service quality) and between Customer Satisfaction towards Customer Loyalty."'EunilPark, and Ki Joon Kim [14] stated that: "There is an effect between service quality on Customer Loyalty to Customer Satisfaction.'Lisa QixunSiebers, Tao Zhang, and Fei Li [15] stated that: "There is an effect between Price, Product, and Storage image (Positioning) on Customer Loyalty to Customer Satisfaction."

\section{RESEARCH METHOD}

\section{Research Design}

Based on its function, this research is included in descriptive research. Descriptive research is one type of conclusive research which has the main objective of describing something, namely the characteristics or functions of the market. 
Descriptive research is characterized by the formulation of specific hypotheses, so the information required is clearly defined, so that descriptive research is planned and structured [16].

\section{Research Method}

The method used in this research is quantitative method using Structural Equation Modeling(SEM).

\section{Research Setting \& Time}

This research will be conducted at Bank XBCA Area KCU and KCP Pangeran Jayakarta. This research will be conducted for five months starting from February 2017 to August 2017 which includes the activities of proposing preparation, data collection, tabulation and data analysis and report writing.

\section{Population, Sample and Sampling Techniques}

In this multivariate research, the analytical tool used is Structural Equation Modeling (SEM). According to the analytical tool used, the determination of the number of samples is determined by the requirements specified by Hair et. al.[17]. Hair et. al. [17] stated that:"the number of samples taken is at least five times and a maximum of ten times the number of parameters used in the study. This study uses 63 parameters in the form of question items in the questionnaire, so that the minimum sample size taken is 63 multiply 5 is 315 and the maximum sample is 63 multiply 10 is 630. Based on the minimum number of samples that must be taken in this study, the number The samples taken in this study were 315 respondents. The number of samples in this study was determined by considering the adequacy of the data for analysis purposes. Characteristics of respondents are based on several criteria such as age, gender, level of education and profession.

\section{RESULTS AND DISCUSSION}

\section{The Conceptual Research Framework}

Figure 1 shows the Conceptual Research Framework, there are research variables, include: promotion mix, Service Quality, Positioning, Customer Satisfaction, and Customer loyalty.

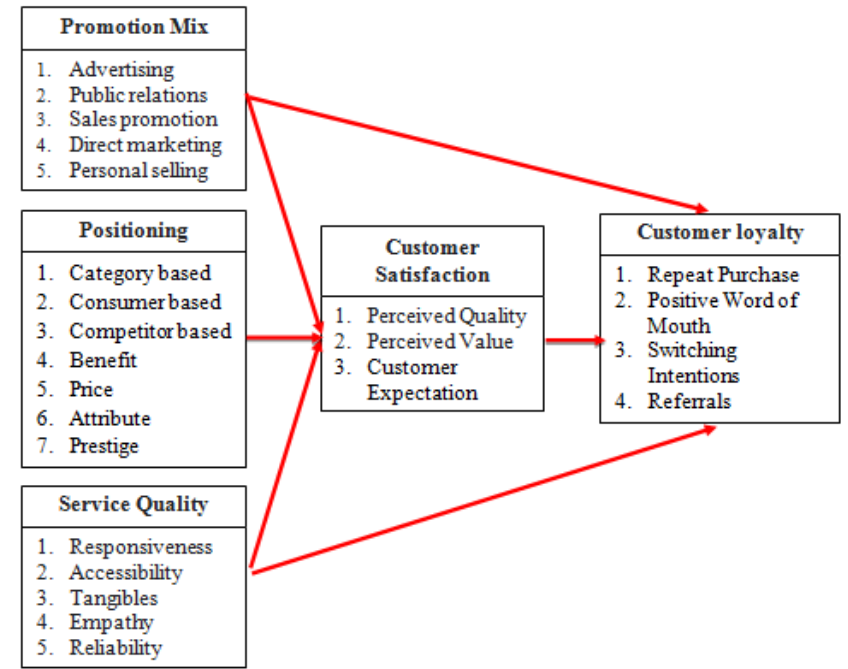

Figure 1. The Conceptual Research Framework [2-15],

\section{Null Hypotheses Test}

Based on the conceptual research framework that has been stated previously, this study has several hypotheses in the form of null hypothesis $\left(\mathrm{H}_{0}\right)$ and alternative hypothesis $\left(\mathrm{H}_{1}\right)$ from each variable, where $\mathrm{H}_{0}$ is a hypothesis assumption that has no effect while $\mathrm{H}_{1}$ is an influential hypothesis assumption.

To test this hypothesis, a statistical test was performed using the calculation of SEM Analysis as a quantitative analysis.

Hypotheses test stated that $\mathrm{H}_{0}$ (Null Hypothesis) is rejected or the variable has an effect if the $\mathrm{t}$ valueis $>1.96$ at significant level, $\alpha$ is $5 \%$ (0.05). The following is an explanation of the relationship between each variable in this study.

$\mathrm{H}_{01}$ : Promotionmix has a positive effect oncustomer satisfaction. $\mathrm{H}_{02}$ : Positioning has a positive effecton the customer satisfaction. $\mathrm{H}_{03}$ : Service Quality has a positive effect oncustomer satisfaction. $\mathrm{H}_{04}$ : Promotionmix has a positive effect oncustomer loyalty. $\mathrm{H}_{05}$ : Positioning has a positive effect oncustomer loyalty.

$\mathrm{H}_{06}$ : Service Quality has a positiveeffect on customer loyalty.

$\mathrm{H}_{07}$ : customer satisfaction has a positiveeffect on customer loyalty. 


\section{Characteristics of Respondents}

Table 1 shows the numbered of respondent (male and female) and the total of respondents. It is known that the customers of Bank XBCA Area KCU and KCP Pangeran Jayakarta are mostly female as many as 161 respondents (51.1\%), while the rest are male as many as 154 respondents $(48.9 \%)$.

Table 1 Respondents Identity Based on Gender

\begin{tabular}{|l|l|l|}
\hline Gender & Frequency & $\begin{array}{l}\text { Percentag } \\
\text { e(\%) }\end{array}$ \\
\hline Male & 154 & 48.9 \\
\hline Female & 161 & 51.1 \\
\hline Total & $\mathbf{3 1 5}$ & $\mathbf{1 0 0 . 0}$ \\
\hline
\end{tabular}

Source: research results processed by the author, 2017

Table 2 Respondents Identity Based on Age

\begin{tabular}{|l|l|l|}
\hline Ages & Frequency & $\begin{array}{l}\text { Percentag } \\
\text { e }(\boldsymbol{\%})\end{array}$ \\
\hline$<21$ years & 9 & 2.9 \\
\hline 21-35 years & 126 & 40.0 \\
\hline 36-50 years & 127 & 40.3 \\
\hline$>50$ years & 53 & 16.8 \\
\hline Total & $\mathbf{3 1 5}$ & $\mathbf{1 0 0 . 0}$ \\
\hline
\end{tabular}

Source: research results processed by the author, 2017

Table 2 shows that the customers of Bank XBCA Area KCU and KCP Pangeran Jayakarta are mostly aged 36-50 years old are 127 respondents (40.3\%), respondents age 21-35 years are 126 respondents $(40 \%)$, respondent age over 50 years as many as 53 respondents (16.8\%), while the rest were under 21 years old as many as 9 respondents $(2.9 \%)$.

Table 3 Respondents Identity Based on Occupation

\begin{tabular}{|l|l|l|}
\hline Occupations & $\begin{array}{l}\text { Frequenc } \\
\mathbf{y}\end{array}$ & $\begin{array}{l}\text { Percenta } \\
\text { ge( } \mathbf{\%})\end{array}$ \\
\hline Civil Servants & 8 & 2.5 \\
\hline Private Employees & 85 & 27.0 \\
\hline Enterpreneurs & 191 & 60.6 \\
\hline Students & 19 & 6.0 \\
\hline Others & 12 & 3.8 \\
\hline Total & $\mathbf{3 1 5}$ & $\mathbf{1 0 0 . 0}$ \\
\hline
\end{tabular}

Source: research results processed by the author, 2017
Table 3 showsthat the customers of Bank XBCA Area KCU and KCP Pangeran Jayakarta mostly work as entrepreneurs as many as 191 respondents $(60.6 \%)$, profession as private employees is 85 respondents (27\%), profession as a student/student is 19 respondents $(6 \%)$, other professions such as lawyers and others were 12 respondents (3.8\%), while the rest were civil servants as many as 8 respondents $(2.5 \%)$.

\section{Table 4 Respondent Identity Based on Length of Time as XBCA Customer}

\begin{tabular}{|l|l|l|}
\hline Length of Time & Frequency & $\begin{array}{l}\text { Percentag } \\
\text { e (\%) }\end{array}$ \\
\hline$<$ 1 year & 17 & 5.4 \\
\hline 1-2 years & 48 & 15.2 \\
\hline$>$ 2 years & 250 & 79.4 \\
\hline Total & $\mathbf{3 1 5}$ & $\mathbf{1 0 0 . 0}$ \\
\hline
\end{tabular}

Source: research results processed by the author, 2017

Table 4 showsthat the length of time being a customer of Bank XBCA Area KCU and KCP Pangeran Jayakarta is mostly more than 2 years as many as 250 respondents (79.4\%), 1-2 years as many as 48 respondents (15.2\%), and less than 1 year as many as 17 respondents $(5.4 \%)$.

\section{Data Types and Sources}

Data sources according to Suharsini Arikunto [18] are the subjects from which data can be obtained. The data used in this study consisted of two types, namely primary data and secondary data. Primary data is data collected through first parties, usually through interviews.

\section{The Effect of Promotion mix towards Customer Satisfaction}

Table 5 shows that the result of the $\mathrm{t}_{\text {-value }}$ is 3.90 . So, it can be concluded that the promotion mix has an effect on customer satisfaction at Bank XBCA Area KCU and KCP Pangeran Jayakarta because the result of the $t$-value is $>1.96$. 
Table 5 Hypothesis Test Results Promotion Mix on Customer satisfaction

\begin{tabular}{|l|l|l|l|}
\hline Variable & $\begin{array}{l}\text { Standardized } \\
\text { Estimate }(\boldsymbol{\beta})\end{array}$ & $\mathbf{t}_{\text {Value }}$ & Information \\
\hline $\begin{array}{l}\text { Promotion } \\
\text { Mix to }\end{array}$ & & & $\begin{array}{l}\mathbf{H}_{01 \quad \text { is }}^{\text {rejected/has }} \\
\text { Customer } \\
\text { Satisfactio } \\
\text { n significant } \\
\text { effect }\end{array}$ \\
\hline
\end{tabular}

Furthermore, the hypothesis $\mathrm{H}_{01}$ has a $\mathrm{t}_{\text {-value }}$ of 3.90 (95\% confidence level) or $\mathrm{H}_{01}$ is rejected because the $t_{-}$value is $>1.96$. This indicates that there is an influence between the promotion mix on customer satisfaction.

This is based on the perception that if XBCA Bank provides the best solution for customers, then the customer will be satisfied to a company and the products sold in that company. Therefore, the researcher concluded that the promotion mix of the staff of the Bank XBCA Area KCU and KCP Pangeran Jayakartamaka customers will use the product, the company must provide easy procedures to respond to any complaints, and the company tries to provide fast and precise service to customers.

\section{The Effect of positioning towards Customer Satisfaction}

Table 6 shows that the result of the $\mathrm{t}$-value is 7.97 . So, it can be concluded that positioning has an effect on customer satisfaction at Bank XBCA Area KCU and KCP Pangeran Jayakarta because the result of the $\mathrm{t}_{\text {-value }}$ is $>1.96$.

Furthermore, the hypothesis $\mathrm{H}_{01}$ has a $\mathrm{t}$-value of 7.97 (95\% confidence level) or $\mathrm{H}_{02}$ is rejected because the $\mathrm{t}_{\text {-value }}$ is $>1.96$. This indicates that there is an influence between the positioning on customer satisfaction.

Table 6 Hypothesis Test Results Positioning on Customer Satisfaction

\begin{tabular}{|l|l|l|l|}
\hline Variable & $\begin{array}{l}\text { Standardi } \\
\text { zed } \\
\text { Estimate } \\
(\boldsymbol{\beta})\end{array}$ & $\mathbf{t}_{\text {value }}$ & $\begin{array}{l}\text { Inform } \\
\text { ation }\end{array}$ \\
\hline $\begin{array}{l}\text { Positioning to } \\
\text { Customer } \\
\text { Satisfaction }\end{array}$ & $\mathbf{0 . 5 3}$ & 7.97 & $\begin{array}{l}\mathrm{H}_{02} \text { is } \\
\text { rejecte } \\
\text { d/has a } \\
\text { signific }\end{array}$ \\
\hline
\end{tabular}

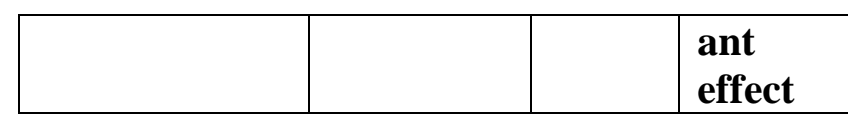

The researcher analyzed that positioning at Bank XBCA Area KCU and KCP Pangeran Jayakarta would affect customer satisfaction. Customer satisfaction can be interpreted as a positive response to the company's products and if the customer has used the product, the customer will recommend other people to use XBCA Bank products, and the customer will not move or be interested in using other products other than Bank products XBCA.

The Effect of Service Quality towards Customer Satisfaction

Table 7 shows that the result of the t-value is 2.48 . So, it can be concluded that service quality has an effect on customer satisfaction at Bank XBCA Area KCU and KCP Pangeran Jayakarta because the result of the t-value $_{\text {is }}>1.96$.

Tablel 7 Hypothesis Test Results of Service Quality on Customer Satisfaction

\begin{tabular}{|c|c|c|c|}
\hline Variable & $\begin{array}{l}\text { Standard } \\
\text { ized } \\
\text { Estimate } \\
(\beta) \\
\end{array}$ & $\mathbf{t}_{\text {value }}$ & Information \\
\hline $\begin{array}{l}\text { Service } \\
\text { Quality to } \\
\text { Customer } \\
\text { Satisfaction }\end{array}$ & 0.10 & 2.48 & $\begin{array}{l}\mathrm{H}_{03} \text { is } \\
\text { rejected/has } \\
\text { a significant } \\
\text { effect }\end{array}$ \\
\hline
\end{tabular}

Null hypothesis $\mathrm{H}_{03}$, two hypotheses are taken, namely $\mathrm{H}_{03}$ and $\mathrm{H}_{13}$ (Alternative Hypothesis 3). Based on the results of hypothesis testing at the $95 \%$ confidence level by considering the $\mathrm{t}_{\text {-value }}$ > 1.96 , it is stated that $\mathrm{H}_{03}$ is rejected because the $\mathrm{t}$ value is $2.48 . \mathrm{H}_{03}$ 's refusal stated that service quality had no effect on customer satisfaction at Bank XBCA Area KCU and KCP Pangeran Jayakarta.

The Effect of Promotion Mix towards Customer Loyalty

Table 8 shows that the result of the $\mathrm{t}$-value is 1.57 . So, it can be concluded that the promotion mix has no effect on customer loyalty at Bank XBCA Area KCU and KCP Pangeran Jayakarta because the result of the $t_{-}$value is $<1.96$. 
Table 8Results of Promotion mix Hypothesis Test on Customer Loyalty

\begin{tabular}{|l|l|l|l|}
\hline Variable & $\begin{array}{l}\text { Standar } \\
\text { dized } \\
\text { Estimate } \\
(\boldsymbol{\beta})\end{array}$ & $\mathbf{t}$ Value & $\begin{array}{l}\text { Informa } \\
\text { tion }\end{array}$ \\
\hline $\begin{array}{l}\text { Promoti } \\
\text { on Mix } \\
\text { to } \\
\text { Custome } \\
\text { r loyalty }\end{array}$ & $\mathbf{0 . 0 5}$ & 1.57 & $\begin{array}{l}\mathbf{H}_{04} \text { is } \\
\text { accepte } \\
\text { d/has no } \\
\text { significa } \\
\text { nt effect }\end{array}$ \\
\hline
\end{tabular}

Furthermore, the hypothesis $\mathrm{H}_{04}$ has a $\mathrm{t}$-value of 1.57 (95\% confidence level) or $\mathrm{H}_{04}$ is rejected because the $\mathrm{t}$-value is $<1.96$. This indicates that there is no an effect between the promotion mix on customer loyalty.

This is based on the perception that if XBCA Bank provides the best solution for customers, then the customer will not be loyal to a company. Therefore, the researcher concluded that the promotion mix of the staff of the Bank XBCA Area KCU is not quite good, and KCP Pangeran Jayakartamaka customers will not use the product, the company must provide a hard-working to respond to any complaints.

\section{The Effect of positioning towards Customer loyalty}

Table 9 shows that the result of the $\mathrm{t}_{-}$value is 3.98 . So, it can be concluded that positioning has an effect on customer loyalty at Bank XBCA Area KCU and KCP Pangeran Jayakarta because the result of the t-value is $>1.96$.

The researcher analyzed that positioning at Bank XBCA Area KCU and KCP Pangeran Jayakarta would affect customer loyalty. Customer loyalty can be interpreted as a positive response to the company's products and if the customer has used the product, the customer will recommend other people to use XBCA Bank products, and the customer will not move or be interested in using other products other than Bank products XBCA.
Table 9 Hypothesis Test Results Positioning on Customer loyalty

\begin{tabular}{|l|l|l|l|}
\hline Variable & $\begin{array}{l}\text { Standardi } \\
\text { zed } \\
\text { Estimate } \\
(\boldsymbol{\beta})\end{array}$ & $\mathbf{t}_{\text {value }}$ & Information \\
\hline $\begin{array}{l}\text { Positioning } \\
\text { to } \\
\text { Customer } \\
\text { loyalty }\end{array}$ & 0.17 & 3.98 & $\begin{array}{l}\mathbf{H}_{05} \text { is } \\
\text { rejected/has } \\
\text { a significant } \\
\text { effect }\end{array}$ \\
\hline
\end{tabular}

The Effect of Service Quality towards Customer loyalty

Table 10 shows that the result of the $\mathrm{t}$-value is 2.95 . So, it can be concluded that service quality has an effect on customer loyalty at Bank XBCA Area KCU and KCP Pangeran Jayakarta because the result of $t_{-}$value is> 1.96 .

Table 10Hypothesis Test Results Service quality Towards Customer loyalty

\begin{tabular}{|l|l|l|l|}
\hline Variable & $\begin{array}{l}\text { Standardized } \\
\text { Estimate }(\boldsymbol{\beta})\end{array}$ & $\mathbf{t}_{\text {value }}$ & $\begin{array}{l}\text { Informatio } \\
\mathbf{n}\end{array}$ \\
\hline $\begin{array}{l}\text { Service } \\
\text { Quality to } \\
\text { Customer } \\
\text { loyalty }\end{array}$ & 0.09 & 2.95 & $\begin{array}{l}\mathbf{H}_{06} \text { is } \\
\text { rejected/ha } \\
\text { s a } \\
\text { significant } \\
\text { effect }\end{array}$ \\
\hline
\end{tabular}

Null hypothesis $\mathrm{H}_{06}$, two hypotheses are taken, namely $\mathrm{H}_{06}$ and $\mathrm{H}_{16}$. Based on the results of hypothesis testing at the $95 \%$ confidence level by considering the $\mathrm{t}_{\text {-value }}>1.96$, it is stated that $\mathrm{H}_{06}$ is rejected because the $\mathrm{t}_{\text {-value }}$ is $2.95 . \mathrm{H}_{03}$ 's refusal stated that service quality had no effect on customer satisfaction at Bank XBCA Area KCU and KCP Pangeran Jayakarta.

\section{The Effect of Customer Satisfaction towards Customer loyalty}

Table 11 shows that the result of the $t_{-}$value is 10.35. So, it can be concluded that customer satisfaction has an effect on customer loyalty at Bank XBCA Area KCU and KCP Pangeran Jayakarta because the result of the $t$-value is $>1.96$. Null hypothesis $\mathrm{H}_{07}$, two hypotheses are taken, namely $\mathrm{H}_{07}$ and $\mathrm{H}_{17}$ (Alternative hypothesis 7 ). Based on the results of hypothesis testing at the $95 \%$ confidence level by considering the $t^{-}$value $>$ 
1.96, it is stated that $\mathrm{H}_{07}$ is rejected because the $\mathrm{t}$ value is $10.35 . \mathrm{H}_{07}$ 's refusal stated that customer satisfaction has an effect on customer loyalty at Bank XBCA Area KCU and KCP Pangeran Jayakarta.

Table 11Hypothesis Test Results of Customer Satisfactionon Customer loyalty

\begin{tabular}{|c|c|c|c|}
\hline Variable & $\begin{array}{l}\text { Standardi } \\
\text { zed } \\
\text { Estimate } \\
\text { ( } \beta)\end{array}$ & $\mathbf{t}_{\text {value }}$ & $\begin{array}{l}\text { Inform } \\
\text { ation }\end{array}$ \\
\hline $\begin{array}{l}\text { Customer } \\
\text { Satisfactio } \\
\text { n to } \\
\text { Customer } \\
\text { loyalty }\end{array}$ & 0.68 & 10.35 & $\begin{array}{l}\mathrm{H}_{07} \text { is } \\
\text { rejecte } \\
\text { d/has a } \\
\text { signific } \\
\text { ant } \\
\text { effect }\end{array}$ \\
\hline
\end{tabular}

\section{CONCLUSION}

Several conclusions can be drawn as follows:

1. Based on the results of hypothesis testing at the $95 \%$ confidence level by considering the $\mathrm{t}_{\text {-value }}>1.96$, it is stated that $\mathrm{H}_{01}$ is rejected because the $t$-value is 3.97 , it means that the promotion mix has an effect on customer satisfaction at the Bank XBCA Area KCU and KCP Pangeran Jayakarta.

2. Based on the results of hypothesis testing at the $95 \%$ confidence level by considering the $t$-value $>1.96$, it is stated that $\mathrm{H}_{02}$ is rejected because the $t$-value is 7.97 , it means that the positioning has an effect on customer satisfaction at Bank XBCA Area KCU and KCP Pangeran Jayakarta.

3. Based on the results of hypothesis testing at the $95 \%$ confidence level by considering the $t$-value $>1.96$, it is stated that $\mathrm{H}_{03}$ is rejected because the t-value is 2.48 , it means that service quality has an effect on customer satisfaction at the Bank XBCA Area KCU and KCP Pangeran Jayakarta.

4. Based on the results of hypothesis testing at the $95 \%$ confidence level by considering the $t_{- \text {value }}<1.96$, it is stated that $\mathrm{H}_{04}$ is rejected because the $\mathrm{t}$-value is 1.57 , it means that promotion mix hasno an effect on customer loyalty at Bank XBCA Area $\mathrm{KCU}$ and KCP Pangeran Jayakarta.

5. Based on the results of hypothesis testing at the $95 \%$ confidence level by considering the $\mathrm{t}$-value $>1.96$, it is stated that $\mathrm{H}_{05}$ is rejected because the $t$-value is 3.98 , it means that positioning hasan effect on customer loyalty at Bank XBCA Area KCU and KCP Pangeran Jayakarta.

6. Based on the results of hypothesis testing at the $95 \%$ confidence level by considering the $\mathrm{t}$-value $>1.96$, it is stated that $\mathrm{H}_{06}$ is rejected because the $t$-value is 2.95 . It means that service qualityhad an effect on customer loyalty at Bank XBCA Area KCU and KCP Pangeran Jayakarta.

7. Based on the results of hypothesis testing at the $95 \%$ confidence level by considering the $\mathrm{t}_{\text {-value }}>1.96$, it is stated that $\mathrm{H}_{07}$ is rejected because the $\mathrm{t}_{\text {-value }}$ is 10.35 . It means that customer satisfaction has an effect on customer loyalty at Bank XBCA Area KCU and KCP Pangeran Jayakarta.

\section{Recommendation}

Some recommendations in this research are:

a. Further research can be done by looking at the limitations of this research which can be used as a source of ideas for the 
development of this research in the future.

b. The direct effect of promotional mix on customer loyalty is $0.06(6 \%)$ and indirect effect through customer loyalty is $0.04(4 \%)$. The direct effect of Service quality on customer loyalty is 0.56 (56\%) and the indirect effect through customer loyalty is $0.44(44 \%)$. The direct effect of positioning on customer loyalty is $0.06(6 \%)$ and the indirect effect through customer loyalty is 0.08 $(8 \%)$. The direct effect of customer satisfaction on customer loyalty is 0.06 $(6 \%)$. For this reason, researchers are advised to include other variables that still affect customer loyalty. at Bank XBCA Area KCU and KCP Pangeran Jayakarta.

c. Future research should direct research to a broader research object by taking a character other than in the Bank XBCA Area KCU and KCP Pangeran Jayakarta, to find out more about overall customer loyalty.

\section{REFFERENCES}

[1] The Republic of Indonesia Law Number 10 of 1998 dated November 10, 1998 Article 1 concerning banking.

[2] M.Karunanithy1, S.Sivesan. 2013. An Empirical Study on the Promotional Mix and Brand Equity:Mobile Service Providers. Journal of Industrial Engineering Letters. Vol.3, No.3, pp. 19.ISSN 2224-6096 (Paper) ISSN 22250581 (online).www.iiste.org.

[3] https://en.wikipedia.org/wiki/Positioning_(marketi ng). Accessed at 31 December, 2020.

[4] https://economictimes.indiatimes.com/definition/po sitioning. Accessed at31 December, 2020.

[5] https://www.promodo.com/blog/brandpositioning-how-to-choose-a-positioningstrategy-for-your-brand/ Accessed at 31 December, 2020.

[6] Nasith, Ali, and BSAPurwono. 2019. Service Quality Implementation to Increase the Youngsters' Parishes Satisfaction at ABCChurch. Journal of Advances Research in Dynamical \& Control Systems, Vol. 11, No. 11, pp. 157-162.

[7] Zeithaml, Valerie A. and A Parasuraman, Leonard L Berry. 1990. Delivering Quality Service. The Free Press. New York.

[8] Parasuraman, A. 2002. Service Quality and productivity: a synergistic perspective. Journal Managing Quality, Vol. 12, No. 1, pp. 6-9.

[9] Kotler, Philip. 2000. Marketing Management. The Millennium Edition. New Jersey.

[10] Angelova,Biljana, and Jusuf Zekiri. 2011. Measuring Customer Satisfaction with Service Quality Using American Customer Satisfaction Model (ACSI Model). International Journal of Academic Research in Business and Social Sciences. October 2011, Vol. 1, No. 3. Pp. 232-258. ISSN: 2222-6990

[11] Virmani,Megha, and Manoj Kumar Dash. 2013. Modelling Customer Satisfaction for Business Services. Journal of Sociological Research. ISSN 1948-5468 2013, Vol. 4, No.2, pp. 51-60.

[12] Ching-Sung Lai, and Minh Chi Nguyen. 2017. Factors Affecting Service Quality, CustomerSatisfaction and Loyalty of Mobile Phone ServiceProviders in Vietnam.The International Journal Of Organizational Innovation. Vol. 10, No. 2, October 2017, Pp. 75-86.

[13] Matelong, Nebert, and Bennard Nassioma. 2013. Determinants of Service Quality of Customers: An Overview of Loyalty. Lap Lambert Academic Publishing. Saarbrucken. Germany.

[14] Park, Eunil, and Ki Joon Kim. 2018. What drives "customer loyalty"? The role of corporate social responsibility. John Wiley \& Sons, Ltd and ERP Environment. Sustainable Development. 2019;27, pp. 304-311.

[15] Siebers, Lisa Qixun, Tao Zhang, and Fei Li. 2019. "Retail Positioning Through Customer Satisfaction:AnAlternative 
Explanation to the Resource-based View". https://

doi.org/10.1080/0965254X.2013.817478

[16] Maholtra, N K.. 1993.Marketing Research: An Applied Orientation, Fourth Edition, Prentice Hall, New Jersey.

[17] Hair, J F., Anderson, RE., Tatham, RL, and Black, WC. 1998. Multivariate Data Analysis, Fifth Edition, Prentice Hall, New Jersey.

[18] Arikunto, Suharsini. 2005. Manajemen Penelitian. Edisi Revisi. Penerbit Rineksa Cipta. Jakarta. 